\section{First reported outbreak of green tobacco sickness in Brazil}

\author{
Primeiro relato do surto da doença da \\ folha verde do tabaco no Brasil
}

\author{
Patricia Pereira Vasconcelos de Oliveira 1 \\ Camila Brederode Sihler 1 \\ Lenildo de Moura 1 \\ Deborah Carvalho Malta 1 \\ Maria Célia de Albuquerque Torres 2 \\ Sandra Márcia da Costa Pereira Lima 3 \\ Ana Lucia Alves de Lima 3 \\ Carlos Eduardo Leite 4 \\ Vera Luiza da Costa-e-Silva 5 \\ Jeremy Sobel 1 \\ Tatiana Miranda Lanzieri 1
}

\section{Introduction}

Dermal absorption of nicotine from the tobacco plant (Nicotiana tabacum) can cause a self-limited syndrome called Green Tobacco Sickness, characterized by nausea, vomiting, dizziness, weakness and headache, affecting tobacco workers during the harvest season. Diagnosis is based on the triad of a history of exposure to tobacco farming, clinical presentation, and elevated nicotine or cotinine levels 1,2,3,4,5,6. Cotinine, the main metabolite of nicotine measurable in saliva, blood and urine, is widely used as a measure of nicotine exposure 7 . Several chromatographic assays are used to quantify cotinine in clinical samples 8,9 .

The incidence and prevalence of green tobacco sickness have been described in the United States, India, Japan, Malaysia and Italy $6,7,10$. The condition has not been reported in any country of the Latin American region or in Brazil, which is the second largest tobacco producer in the world 6 with more than 190,000 family farmer families involved in the farming of tobacco.

A review of the Brazilian National Reportable Diseases System database 11 demonstrated a seasonal increase in cases of acute intoxication in the Arapiraca region, State of Alagoas, Northeastern Brazil. Cases were reported as acute pesticide intoxication among tobacco workers during the months of August and September, when tobacco harvesting occurs 12 . However, pesticide use is 
minimal during the harvest season, leading to a suspicion that the cases might be due to green tobacco sickness 6,7,10.

We therefore conducted an epidemiologic investigation to test the hypothesis that these outbreaks of acute intoxication were due to green tobacco sickness, to identify risk factors associated with the disease, discuss and initiate control and prevention measures. Such action is in line with articles 17 and 18 of the WHO Framework Convention on Tobacco Control, agreed by Brazil in 2005, and calls for the provision of support for economically viable alternative activities and to the protection of the environment and people's health in respect to tobacco cultivation 13 .

\section{Methods}

We conducted a 1:1 matched case-control study between August 1 and September 25, 2007 in the region of Arapiraca. The region consists of 11 municipalities wherein dark tobacco or "tobacco rope" (twisted raw tobacco leaves) is farmed, with an overall population of approximately 406,546 inhabitants (Instituto Brasileiro de Geografia e Estatística. http://www.ibge.gov.br, accessed on Jul/2007).

We defined a case-patient as a person who was diagnosed by a health care professional with acute intoxication during the study period and had a cotinine level over 10ng/mL detected by laboratory examination. The control was a household member or neighbor of a case-patient who did not present symptoms of acute intoxication in the seven days preceding the interview. Neighbor controls were selected among members of the household to the left of the case-patient's house, by enrolling the first person by alphabetic order present at the time of visit. Because tobacco farming is an activity involving all family members, being all exposed, age was not considered in the matching.

We collected data using a standardized questionnaire that included demographics, clinical variables, alcohol and tobacco consumption, and exposure to the various phases of tobacco farming and to pesticides. Because cotinine is a temporary nicotine metabolite, we considered as non-smokers those persons that had never used tobacco products or those who stopped smoking at one month before the interview/urine sample collection. The variables included in the analysis were sex, tobacco use, participation in tobacco growing exclusively, work in tobacco leaf harvesting, work for less than five years in tobacco farming, handling dry tobacco leaves, use of pesticides in the preceding seven days, type of pesticide used, work in sweat-moistened or in dew-moistened clothes, consumption of milk or sweets during work.

We collected urine samples to determine cotinine levels from case-patients and controls using the High Pressure Liquid Chromotography (HPLC) method 8,9,12. The instrumentation and chromatographic conditions of all chemicals were HPLC grade. Acetonitrile, methanol, acetic acid (glacial), sodium acetate trihydrate, citric acid monohydrate and triethylamine were purchased from Merck (Darmstadt, Germany). Pure cotinine and 2-phenylimidazole was obtained from Cerilliant (Round Rock, USA) and the Sigma Chemical Company (Saint Louis, USA), respectively. Ultra pure water was obtained from a Millipore Corporate Milli-Q water system (Billerica, USA).

A high-performance liquid chromatography equipped with an isocratic pump, ultraviolet detector, degasser and manual injection system (all HPLC components and software ChemStation were from Agilent Technologies Inc., Santa Clara, USA) was used. Chromatographic separations were performed using a reverse-phase column (150mm vs. $4.6 \mathrm{~mm}$, $5 \mu \mathrm{m}$ Zorbax Elcipse XDB $\mathrm{C}-8)$. The column was protected by a guard column (4.6 vs. $12.5 \mathrm{~mm}, 5 \mu \mathrm{m}$ Zorbax Elcipse XDB $\mathrm{C}-8)$ and was maintained at the temperature of $22 \pm 2^{\circ} \mathrm{C}$. The mobile phase was a mixture of ultra pure water: methanol: sodium acetate $0.1 \mathrm{M}$ : acetonitrile (50:15:25:10, v/v), with $1 \mathrm{~mL}$ of citric acid $0.034 \mathrm{~mol} / \mathrm{L}$ and $5.0 \mathrm{~mL}$ of triethylamine added for each liter of solution. The flow rate of $0.5 \mathrm{~mL} /$ min was maintained isocratically, the ultraviolet detector was set at $260 \mathrm{~nm}$ and the total run time was 8 minutes. As the internal standard we used 2-phenylimidazole. The detection limit of method was $5 \mathrm{ng} / \mathrm{mL}$ and the limit of quantification was $10 \mathrm{ng} / \mathrm{mL}$. The sample was prepared with two milliliters of urine treated with $25 \mu \mathrm{L}$ of $\mathrm{NaOH}$ $10 \mathrm{M}$ and $100 \mu \mathrm{L}$ of internal standard $(10 \mu \mathrm{g} / \mathrm{mL})$, then extracted with $4.0 \mathrm{~mL}$ of dichloromethane. The organic phase was totally dried with nitrogen at room temperature. Subsequently, $100 \mu \mathrm{L}$ of the mobile phase was added and $20 \mu \mathrm{L}$ was injected into HPLC.

Statistical analysis included stratification of cases and controls by smoking status, as described previously 10. The McNemar chi-square test was used in univariate analysis and the Kruskal-Wallis test for analysis of laboratory data (continuous data). The mach odds ratio (mOR) was used as the measure of association. To identify exposures independently associated with illness, a conditional logistic regression model was used including exposures showing significant 
$(\mathrm{p}<0.05)$ association with illness on univariate analysis and using a stepwise backward elimination strategy to calculate the adjusted OR. Analyses were performed using Epi Info 6.04d and 3.5 (Centers for Disease Control and Prevention, Atlanta, USA).

The study was deemed a surveillance and evaluation activity by the Brazilian Ministry of Health and therefore exempt by law from IRB review and ethics committee approval, involving only oral approval by participants.

\section{Results}

We identified 130 persons meeting the case-definition, of whom 107 (82\%) could be contacted for interview. Among the cases, 57 (53\%) were male and median age was 21 (range, 8-58) years. The epidemiologic curve shows cases starting on August 6, 2007, peaking between August 20 and September 1, and the last 14 cases occurring on August 22 (Figure 1). The most commonly reported symptoms were dizziness, weakness, vomiting, nausea and headache (Table 1). Most cases described themselves as of mixed race $(72 \%)$ or white $(20 \%)$ and $45 \%$ had $\geq 4$ years of schooling and 34\% 1-4 years of schooling. Among the cases, $69(65 \%)$ denied alcohol consumption, 82 (77\%) reported never smoking, 13 (12\%) were former smokers (stopped at least a month before the interview) and 12 (11\%) were regular smokers. The median age for initiation of smoking was 15 (range, 15-22). 47 cases (49\%) reported the presence of a smoker at home.

On univariate analysis, a statistically significant association was found between illness and male sex, being a non-smoker, participating exclusively in tobacco growing, working in tobacco leaf harvesting and working for less than five years in tobacco farming. Case-patients were more likely $(\mathrm{mOR}=5.2,95 \% \mathrm{CI}: 2.0-17.3)$ to be non-smokers (former smoker or never smoker) compared to regular smokers. Handling dry tobacco leaves while producing "tobacco rope" alone was protective. On multivariate analysis, exposures independently associated with illness were male, non-smokers and worked in tobacco leaf harvesting (Table 2).

None of the following exposures were significantly associated with illness: age less than 21 years old $(\mathrm{mOR}=1,0 ; 95 \% \mathrm{CI}$ : 0,31-4,97), use of pesticides in the preceding seven days (mOR $=1.2 ; 95 \% \mathrm{CI}: 0.3-1.2$ ), type of pesticide used as metamifofos ( $\mathrm{mOR}=1.3$; 95\%CI: 0.29.1), deltamethrin ( $\mathrm{mOR}=1.5,95 \% \mathrm{CI}: 0.5-5.1)$, lambda-cihalotrim $(\mathrm{mOR}=1.2 ; 95 \% \mathrm{CI}$ : 0.3 5.0) and imidacloprid ( $\mathrm{mOR}=1.1$; 95\%CI: 0.3 3.7 ), alcohol consumption $(\mathrm{mOR}=0.6$; $95 \% \mathrm{CI}$ : 0.3-1.2), working in sweat-moistened clothes $(\mathrm{mOR}=1.3 ; 95 \% \mathrm{CI}: 0.7-2.5)$ working in dewmoistened clothes $(\mathrm{mOR}=1.33$; 95\%CI: 0.5-3.6), being a passive smoker ( $\mathrm{mOR}=1.2$; $95 \% \mathrm{CI}$ : 0.6 2.7 ) and consuming milk ( $\mathrm{mOR}=1.3$; 95\%CI: 0.4-4.66) or sweets (mOR $=1.3$; IC95\%: $0.5-3.3$ ) during work.

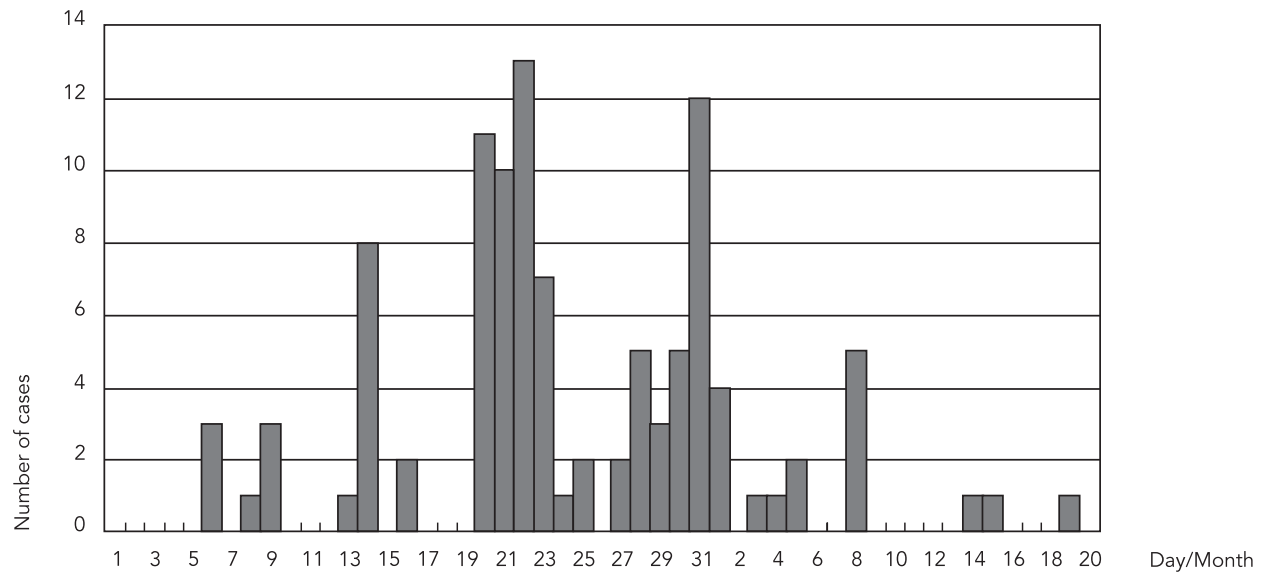


Urinary cotinine level read-outs were stratified by smoking status. Among smokers, there was no significant difference in the median urine cotinine levels of case-patients $(811 \mathrm{ng} / \mathrm{mL}$; interval, 98-5,930) and controls (1,293ng/mL; interval, 90-3,580); $(\mathrm{p}=0.49)$. Among non-smokers, there was a significant difference between urinary cotinine levels of case-patients $(288 \mathrm{ng} / \mathrm{mL}$; interval, 18-6,313) and controls (156ng/mL; interval, 0-1,908); ( $\mathrm{p}=0.006$ ) (Table 3$)$.

\section{Discussion}

Our clinical, epidemiological and laboratory findings were consistent with green tobacco sickness diagnosis. The signs and symptoms observed among the workers of the region (vomit, nausea, headache and dizziness) were also described by

Table 1

Signs and symptoms of case-patients. Arapiraca Region, Alagoas State, Brazil, 2007.

\begin{tabular}{lll}
\hline Signs and symptoms $(\mathbf{N}=\mathbf{1 0 7})$ & $\mathbf{n}$ & $\%$ \\
\hline Dizziness & 95 & 90 \\
Weakness & 93 & 88 \\
Vomiting & 88 & 83 \\
Nausea & 87 & 82 \\
Headache & 62 & 59 \\
Blurred vision & 55 & 52 \\
Dyspnea & 33 & 31 \\
Colic & 28 & 26 \\
Tremors & 15 & 20 \\
Diarrhea & 19 & 18 \\
Skin irritation & 15 & 14 \\
Fainting & 13 & 12 \\
\hline
\end{tabular}

Arcury et al. 2,3,4 during tobacco production in Hispanic farmworkers in the USA. In our study, case-patients were identified during the period of tobacco harvesting in the region, when greatest exposure of the farmers to the nicotine in the tobacco leaves occurs 5,6,10.

We found a frequency of smokers in relation to non-smokers comparable to existing surveillance data from VIGITEL, a national telephone survey for risk factors for non-communicable diseases, which has shown a frequency of adult smokers ( $\geq 18$ years) of $12 \%$ in Alagoas State in 2007. Although the survey was conducted in an urban population, we found a similar prevalence of smoking in the rural region of Arapiraca 14

In the international literature a relationship between tobacco harvesting during rainy days and green tobacco sickness has been observed $5,6,15,16$. The absorption of nicotine through the skin is facilitated by the moisture. We were not able to measure this association in our study; however some interviewees reported an increase in the number of people with the symptoms and signs of green tobacco sickness during rainy days. This should be further explored in future studies.

Although in the case-control analysis we observed that case-patients were more likely to be male, we found no biological differences that would explain the greater risk. This could be due to the fact that the activity is more usual among men than women in this region, which was also reported by McBride et al. 5 . Furthermore, it could be caused by selection bias, since we interviewed as controls those household members that were present in the house at the time of visit, thus men in a healthy state could be working in the field while women were handling dry tobacco leaves, which were found to be protective against green tobacco sickness.

Table 2

Risk factors associated with acute poisoning on univariate and multivariate analysis. Arapiraca Region, Alagoas State, Brazil, 2007.

\begin{tabular}{|c|c|c|c|c|c|c|c|}
\hline \multirow[t]{2}{*}{ Risk factors $(\mathrm{N}=214)$} & \multicolumn{2}{|c|}{ Cases } & \multicolumn{2}{|c|}{ Controls } & \multirow[t]{2}{*}{ mOR } & \multirow{2}{*}{$\begin{array}{l}\text { Adjusted OR } \\
\qquad(95 \% \mathrm{Cl})\end{array}$} & \multirow[t]{2}{*}{ p-value } \\
\hline & $\mathbf{n}$ & $\%$ & $\mathbf{n}$ & $\%$ & & & \\
\hline Male sex & 57 & 53 & 34 & 32 & & & \\
\hline Non-smoker & 95 & 89 & 73 & 68 & $5.2(2.0-17.3)$ & $7.0(2.6-19.1)$ & $<0.001$ \\
\hline Work in tobacco leaf harvest & 85 & 79 & 65 & 61 & $2.7(1.3-5.7)$ & $2.7(1.2-6.0)$ & 0.014 \\
\hline Work less than 5 year with tobacco & 46 & 43 & 26 & 24 & $3.5(1.5-8.9)$ & $2.1(0.8-5.4)$ & 0.12 \\
\hline Work exclusively in tobacco growing & 97 & 91 & 85 & 79 & $3.4(1.2-11.8)$ & $1.6(0.4-7.1)$ & 0.54 \\
\hline Hand dry tobacco leaves & 84 & 78 & 59 & 55 & $0.3(0.1-0.6)$ & $0.4(0.1-1.0)$ & 0.06 \\
\hline
\end{tabular}


Urinary cotinine levels in smokers and non-smokers of casepatients and controls. Arapiraca Region, Alagoas State, Brazil, 2007. ( $\mathrm{N}=214)$.

\begin{tabular}{|c|c|c|c|c|}
\hline & \multirow[t]{2}{*}{$\mathrm{n}$} & \multicolumn{2}{|c|}{$\begin{array}{c}\text { Urinary cotinine } \\
\qquad(\mathrm{ng} / \mathrm{mL})\end{array}$} & \multirow[t]{2}{*}{$p$-value } \\
\hline & & Median & Interval & \\
\hline \multicolumn{5}{|l|}{ Smokers } \\
\hline Case-patients & 12 & 811 & $98-5,930$ & 0.49 \\
\hline Controls & 34 & 1,293 & $90-3,580$ & \\
\hline \multicolumn{5}{|l|}{ Non-smokers } \\
\hline Case-patients & 91 & 288 & $18-6,313$ & 0.006 \\
\hline Controls & 73 & 156 & $0-1,908$ & \\
\hline
\end{tabular}

In our study, we have observed that the case-patients were most commonly non-smokers rather than smokers. A study performed by Arcury et al. 4 found that smoking may reduce dermic absorption of nicotine, which could be caused either by the vessel constriction due to tobacco consumption or the metabolic adaptation or acquired nicotine tolerance by tobacco consumers. This tolerance may be explained by the increase in nicotine receptors found in smokers which cause a non-responsive phase after binding of nicotine to receptors. This phenomena is called "taquiphilaxis" which is the introduction of low doses of toxic products protecting the organism from sudden administration of new doses in a short interval 17. However, if the exposure to nicotine is seriously exceeded as observed in occupational exposure, green tobacco sickness may be observed in smokers as well, in addition to the several effects of smoking on health, such as lung, trachea and bronchial cancer and heart disease 18,19 .
High levels of urine cotinine were also found in other studies. Onuki et al. 7 also observed a significant increase in the level of cotinine in non-smoking farm workers suggesting dermal absorption of nicotine contained in tobacco leaves. Arcury et al. 20 suggested a positive relationship between high levels of cotinine and green tobacco sickness among smokers, occasional smokers and non-smokers, with higher levels of saliva cotinine, with a greater risk of presenting symptoms and signs of green tobacco sickness especially among non smokers 20 . The main limitation of our study was that we were not able to control the exposure of tobacco growers to passive smoking, which may have been a confounder in the urinary cotinine analysis.

The results of this study were discussed with health professionals in the municipality, local government officials and workers. The importance of an accurate and timely diagnosis was highlighted to health professionals to improve knowledge of the magnitude of the disease. Likewise, increased awareness of the target population about the risks of green tobacco sickness is critical for introducing protective measures for farmers such as gloves, appropriate clothing and the washing of hands during the work, as recommended by Curwin et al. 21 .

Additional studies in other tobacco growing areas in the country will be important in order to better understand risk factors for the disease and identify adequate prevention measures for effective interventions. Furthermore, the data presented in this study will support setting up a specific surveillance system for tobacco-producing areas. For example, the long term effect of environmental/occupational exposure to cotinine in children is unknown. This study also highlights the need for including in the public health agenda an economically viable and sustainable alternative for family farming of tobacco, as it is an activity that is hazardous to workers' health. 


\section{Resumo}

A absorção dérmica da nicotina por agricultores que trabalham com o cultivo do tabaco provoca uma intoxicação aguda denominada doença da folha verde do tabaco. Apesar de o Brasil ser o segundo produtor mundial de tabaco, a doença da folha verde do tabaco ainda não havia sido relatada no país. Conduzimos um estudo de caso-controle pareado (1:1) entre pessoas envolvidas na cultura do tabaco para determinar a ocorrência de doença da folha verde do tabaco na Região Nordeste do Brasil e identificar fatores de risco. Um paciente-caso foi a pessoa que no período de estudo foi diagnosticada de intoxicação aguda por profissionais de saúde e teve nível de cotinina acima de 10ng/mL pela Cromatografia Líquida de Alta Eficiência. Identificamos 107 pacientes-caso. Principais sinais e sintomas observados foram tontura, fraqueza, vômito, náusea e cefaléia. Foram associados ao adoecimento ser do sexo masculino, não-fumantes e ter trabalhado na fase da colheita do tabaco. A mediana de cotinina urinária entre os pacientes-caso foi maior que os controles. Os dados epidemiológicos e laboratoriais confirmaram pela primeira vez a doença da folha verde do tabaco no Brasil.

Tabaco; Nicotina; Doenças Profissionais; Agricultura

\section{Contributors}

P. P. V. Oliveira participated in the study conception and design, field work and data collection, data analysis and interpretation, writing of the manuscript and approved its final version. C. B. Sihler participated in the study conception and design, field work and data collection, writing of the manuscript and approved its final version. L. Moura participated in the study conception and design, interpretation of results, writing of the manuscript and approved its final version. D. C. Malta participated in the study design and conception, interpretation of results, writing of the manuscript and approved its final version. M. C. A. Torres was involved in the writing of the manuscript and approved its final version. S. M. C. P. Lima participated in data collection and data entry, writing and review of the manuscript and approved its final version. A. L. A. Lima participated in data collection and data entry, writing and review of the manuscript and approved its final version. C. E. Leite participated in data collection and data entry, writing and review of the manuscript and approved its final version. V. L. Costa-eSilva participated study design and conception, writing and review of the manuscript and approved its final version. J. Sobel participated study design and conception, writing and review of the manuscript and approved its final version. T. M. Lanzieri participated in the study conception and design, data analysis, interpretation of results, writing and review of the manuscript and approved its final version.

\section{Acknowledgements}

We are grateful to the Health Authorities of the municipalities of Arapiraca, Girau do Ponciano, Craíbas, Lagoa da Canoa and Feira Grande; to the Agriculture Authority of the municipality of Arapiraca; and to the Rural Workers' Trades-union from the region. We are also grateful for the support received from Jorge Kell and Eduardo Macario, technical officers of the Brazilian Ministry of Health and to Silvana Rubano Barreto Turci, head of the Cancer and Environment Unit of the National Institute of Cancer of Brazil.

\section{References}

1. Trapé-Cardoso M, Bracker A, Grey M, Kaliszewski M, Oncken C, Ohannessian C, et al. Shade tobacco and green tobacco sickness in Connecticut. J Occup Environ Med 2003; 45:656-61.

2. Arcury TA, Quandt SA, Preisser JS. Predictors of incidence and prevalence of green tobacco sickness among Latino farmworkers in North Carolina, USA J Epidemiol Community Health 2001; 55:818-24.

3. Arcury T, Quandt S, Preisser J, Norton D. The incidence of green tobacco sickness among Latino farmworkers. J Occup Environ Med 2001; 43:601-9.
4. Arcury T, Quandt S, Garcia D, Preisser J, Norton D, Rao P. A clinic-based, case-control comparison of green tobacco sickness among minority farmworkers: clues for prevention. South Med J 2002; 95: 1008-11.

5. McBride JS, Altman DA, Klein M, White W. Green tobacco sickness. 1998. Tob Control 1998; 7:294-8.

6. Schimitt N, Schimitt J, Kouimintzis D, Kirch W. Health risks in tobacco farm workers: a review of the literature. J Public Health 2007; 15:255-64. 
7. Onuki M, Yokoyama K, Kimura K, Sato H, Nordin RB, Lin Naing YM, et al. Assessment of urinary cotinine as a marker of nicotine absorption from tobacco leaves: a study on tobacco farmers in Malaysia. J Occup Health 2003; 45:140-5.

8. Ceppa F, Jahiri YE, Mayaudon H, Dupuy O, Burnat P. High-performance liquid chromatographic determination of cotinine in urine in isocratic mode. J Chromatogr B Biomed Sci Appl 2000; 742:115-22.

9. Rabbaa-Khabbaz L, Daoud R, Karam-Sarkis D. A simple, sensitive, and rapid method for determination of cotinine in urine by high-performance liquid chromatography with UV detection. J Chromatogr Sci 2006; 44:535-8.

10. Araki S, Nordin R, Yokoyama K, Kitamura F. Pesticide use, acute symptoms, and nicotine absorption among tobacco farmers in Malaysia. Asian-Pacific Newsletter on Occupational Health \& Safety 2005; 12:6-8.

11. Ministério da Saúde. Sistema de Informação de Agravos de Notificação - SINAN. Normas e rotinas, versão 5.1. Brasília: Ministério da Saúde; 2004.

12. Cattaneoa R, Alegretti AP, Segebin FR, Abreu CM, Petersen GO, Chatkin JM, et al. Validação do método para determinação de cotinina em urina por cromatografia líquida de alta eficiência. Rev Bras Toxicol 2007; 19:21-7.

13. World Health Organization. Who framework convention on tobacco control. Geneva: World Health Organization; 2003.
14. Secretaria de Gestão Estratégica e Participativa, Secretaria de Vigilância à Saúde, Ministério da Saúde. VIGITEL Brasil 2007: vigilância de fatores de risco e proteção para doenças crônicas por inquérito telefônico. Brasília: Ministério da Saúde; 2007.

15. Auslander M, Ballard T, Brandt V, Ehlers J, Freund E, Halperin W. Green tobacco sickness: occupational nicotine poisoning in tobacco worker. Arch Environ Health 1995; 50:384-9.

16. Petersom EA, Stroube RB, Barret E, O'Dell VL. Green tobacco sickness, Scoth County, Virginia. Epidemiol Bull 1999; 99:1-2.

17. Rosemberg J. Nicotina, droga universal. http:// www.inca.gov.br/tabagismo/publicacoes/nicotina. pdf (accessed on 31/Oct/2009).

18. Centers for Disease Control and Prevention. Green tobacco sickness in tobacco harvesters. MMWR Morb Mortal Wkly Rep 1993; 42:237-40.

19. Parikh J, Gokani V, Doctor P, Kulkarni P, Shah A, Saiyed H. Acute and chronic health effects due to green tobacco exposure. Am J Ind Med 2005; 47:494-9.

20. Arcury TA, Quandt SA, Preisser JS, Bernert JT, Norton D, Wang J. High levels of transdermal nicotine exposure produce green tobacco sickness in Latino farmworkers. Nicotine Tob Res 2003; 5:315-21.

21. Curwin BD, Hein MJ, Sanderson WT, Nishioka MG, Buhler W. Nicotine exposure and decontamination on tobacco harvesters' hands. Ann Occup Hyg 2005; 49:407-13.

Submitted on 19/Jul/2009

Final version resubmitted on 09/Apr/2010

Approved on 10/Jun/2010 